\title{
Recent developments in the nanostructured materials functionalized with ruthenium complexes for targeted drug delivery to tumors
}

This article was published in the following Dove Press journal:

International Journal of Nanomedicine

4 April 2017

Number of times this article has been viewed

\author{
Prakash Thangavel' \\ Buddolla Viswanath' \\ Sanghyo Kim ${ }^{1,2}$ \\ 'Department of Bionanotechnology, \\ Gachon University, Bokjeong- \\ Dong, Sujeong-Gu, Seongnam-Si, \\ Gyeonggi-Do, ${ }^{2}$ Graduate Gachon \\ Medical Research Institute, \\ Gil Medical Center, Incheon, \\ Republic of Korea
}

\begin{abstract}
In recent years, the field of metal-based drugs has been dominated by other existing precious metal drugs, and many researchers have focused their attention on the synthesis of various ruthenium $(\mathrm{Ru})$ complexes due to their potential medical and pharmaceutical applications. The beneficial properties of $\mathrm{Ru}$, which make it a highly promising therapeutic agent, include its variable oxidation states, low toxicity, high selectivity for diseased cells, ligand exchange properties, and the ability to mimic iron binding to biomolecules. In addition, Ru complexes have favorable adsorption properties, along with excellent photochemical and photophysical properties, which make them promising tools for photodynamic therapy. At present, nanostructured materials functionalized with $\mathrm{Ru}$ complexes have become an efficient way to administer $\mathrm{Ru}$-based anticancer drugs for cancer treatment. In this review, the recent developments in the nanostructured materials functionalized with Ru complexes for targeted drug delivery to tumors are discussed. In addition, information on "traditional" (ie, non-nanostructured) Ru-based cancer therapies is included in a precise manner.
\end{abstract}

Keywords: metallodrugs, nanotechnology, cancer treatment, cell apoptosis, DNA damage, toxicity

\section{Introduction}

Among the currently investigated metal-based chemotherapeutic agents, ruthenium $\mathrm{Ru}$ ) and its compounds hold a promising future as these compounds exhibit different oxidation states and lower toxicity compared to other metal-based drugs. ${ }^{1}$ In general, $\mathrm{Ru}$ compounds with oxidation states II and III have potential applications in the field of medicine, particularly as chemotherapeutic agents for various cancers. ${ }^{2}$ As illustrated in Figure 1, Ru possesses unique properties that make it an attractive anticancer chemotherapeutic agent. In addition, Ru forms various structural dimensions when combined with other compounds, and these combined compounds exhibit various modes of action such as interaction with DNA and activation of DNA damage mechanisms, as well as inhibition of the activities of several enzymes, including extracellular metalloproteases. $^{3}$ The relationship between function and composition of Ru complexes is summarized in Table 1.

Therefore, Ru complexes are considered more efficient, less toxic, and target-specific noncovalent DNA-binding anticancer drugs. ${ }^{4}$ Another property of Ru compounds that makes them ideal candidates for medicinal applications is their ability to mimic iron binding to certain biomolecules such as serum transferrin and albumin, which are utilized by mammals to solubilize and transport iron, thus reducing cellular toxicity. ${ }^{4,5}$
Correspondence: Sanghyo Kim Department of Bionanotechnology, Gachon University, Bokjeong-Dong, Sujeong-Gu, Seongnam-Si, Gyeonggi-Do, Incheon, Republic of Korea

Tel +82 3I 7508554

Email samkim@gachon.ac.kr 


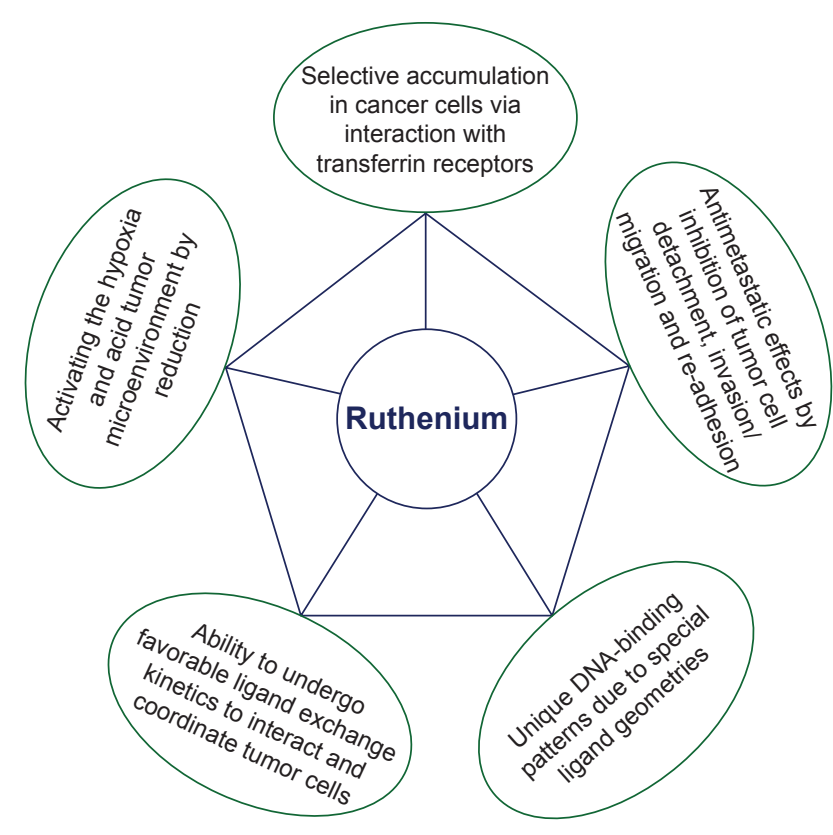

Figure I Properties of ruthenium that make it an attractive chemotherapeutic agent.

In vivo studies demonstrated that rapidly multiplying cells have increased number of transferrin receptors to sequester more metal-loaded transferrin, thus attracting more $\mathrm{Ru} .{ }^{5,6}$ There is confirmation to suggest that $\mathrm{Ru}$ complexes might directly interfere with specific proteins involved in signal transduction pathways, compared to any other metal complexes including iron complexes, and alter cell adhesion and migration processes. ${ }^{7}$ In addition, the redox potential between the different oxidation states of $\mathrm{Ru}$ facilitates the body to catalyze oxidation and reduction reactions depending on the physiological environment. Among the other metal complexes, Ru complexes have different geometries, which allow for the design of compounds with a specific cellular target. ${ }^{8}$ The rigid and well-defined spatial arrangement of a series of Ru complexes has enabled the preparation of highly potent and selective enzyme inhibitors, which is a very helpful characteristic feature in cancer therapy. Moreover, the investigations of Ru complexes in clinical trials attest to the possibility of utilizing non-platinum metal-based compounds in the treatment of cancer. ${ }^{46}$

Because of these unique properties, $\mathrm{Ru}$ is the most promising metal to replace platinum in future medicinal and pharmaceutical applications. However, application of these drugs in cancer treatment has been hampered by the low transport efficiency of their active species to biological targets. This has led to the design and development of new technologies based on nanostructured materials. The nanostructured materials generally act as vectors for metallodrug delivery or simply as protectors of active species of the complexes to enhance their activities and reduce their degradation. ${ }^{9}$ This review focuses on the recent developments in the nanostructured materials functionalized with $\mathrm{Ru}$ complexes for tumor-targeted drug delivery.

\section{Ru complexes and their recent applications in cancer treatment}

Cancer is one of the leading causes of death in the world and is becoming an important topic in scientific research. Cancer cells accumulate multiple mutations that confer them a selective growth advantage over other cells, causing them to grow uncontrollably, become invasive, and eventually spread to other parts of the body. In addition, cancer cells typically exhibit aberrations in signaling pathways that regulate various cellular processes, such as cell growth and division, and cell-to-cell communication. ${ }^{10}$ Therefore, the genetic and phenotypic heterogeneities of cancer cells make cancer a disease that is difficult to treat. Among the effective anticancer treatments, transition metal complexes play important roles in all living systems and have various

Table I Relationship between composition of Ruthenium $(\mathrm{Ru})$ complexes and their functions

\begin{tabular}{|c|c|c|}
\hline $\begin{array}{l}\text { Serial } \\
\text { number }\end{array}$ & Composition of $\mathbf{R u}$ complexes & Function \\
\hline 1 & Ru surrounded by Lewis bases with lone pairs & $\begin{array}{l}\text { These compounds have some ligands that can be hydrolyzed and therefore help to reach } \\
\text { cancerous cells }\end{array}$ \\
\hline 2 & Ru organometallics & $\begin{array}{l}\text { These complexes have displayed high water and air stability and an interesting spectrum } \\
\text { of anticancer activity }\end{array}$ \\
\hline 3 & Ru platinum mixed-metal compounds & $\begin{array}{l}\text { These complexes have the potential of combined efficiency of mechanisms and therefore } \\
\text { have higher selectivity against both neoplastic tumors and metastatic cancer }\end{array}$ \\
\hline 4 & Ru cluster complexes & $\begin{array}{l}\text { These clusters are known to form supramolecular interactions with arenes and other } \\
\text { functions; such interactions are important with respect to their mode of biological activity }\end{array}$ \\
\hline 5 & Ru DNA intercalators & $\begin{array}{l}\text { These complexes exhibit a high cytotoxicity due to the two cis chloride ligands, which } \\
\text { might be exchanged for biological targets as DNA }\end{array}$ \\
\hline 6 & Ru linked with organic directing molecule & $\begin{array}{l}\text { These complexes help to bind Ru directly to the cellular target, which could massively } \\
\text { increase the potency of the drug }\end{array}$ \\
\hline
\end{tabular}


therapeutic applications. ${ }^{11}$ These metals form positively charged ions in aqueous solution that can bind to negatively charged biological molecules. Consequently, the charge can be modified depending on the coordination surroundings involved, leading to the generation of a species that can be anionic, cationic, or neutral. In addition, metal ions with high affinity for electrons can polarize groups that are coordinated to them, fostering the generation of hydrolysis reactions. ${ }^{12}$ The oxidation state of a metal is also an imperative consideration in the design of coordination compounds, as it allows the participation in biological redox chemistry and plays a crucial role in determining the optimal dose and bioavailability of the agent administered. ${ }^{13}$ Furthermore, transition metals can undergo ligand exchange reaction, and this property allows them to interact with and coordinate to biological molecules.

Among the transition metal complexes, Ru-based complexes are regarded as highly promising drug candidates. Therefore, the field of coordination and organometallic chemistry of Ru has expanded considerably over the past few years. ${ }^{14,15}$ As previously discussed, the unique properties of Ru-based complexes, including their high ability to bind nucleic acids and proteins and undergo ligand exchange reaction, the prevalence of the two main oxidation states, $\mathrm{Ru}(\mathrm{II})$ and $\mathrm{Ru}(\mathrm{III})$, as well as the iron-mimicking property when bound to biological molecules have made them potential drug candidates for various medical applications. ${ }^{16}$ In addition, these complexes have reduced toxicity and can be well tolerated in vivo. ${ }^{17}$ Studies have also shown that most $\mathrm{Ru}$ complexes have low systemic toxicity, exhibit slow ligand exchange rates similar to that of platinum compounds, and can accumulate in cancer cells more effectively than platinum. The anticancer mechanisms of Ru complexes have been extensively investigated as illustrated in Table 2 . The various mechanisms that mediate the anticancer activities of Ru complexes include inhibition of topoisomerase activity, inhibition of metastasis, production of reactive oxygen species (ROS), interaction with proteins and DNA, as well as induction of apoptosis. In addition, the anticancer effects of Ru complexes depend largely on the ligand involved, characteristics of the complexes, and the presence of uncoordinated sites in the coordination sphere of the metal center. ${ }^{71}$ As such, much effort has been directed toward exploring the tumor-inhibiting properties of various $\mathrm{Ru}$ complexes..$^{18}$ As listed in Table 2, although a large number of $\mathrm{Ru}$ complexes have shown great promise as potential antitumor agents, only three complexes, NAMI-A, KP1019, and NKP1339 (Table 3), have entered clinical trials. ${ }^{16,19,20}$ Clinically, all the three complexes exhibited promising anticancer activities with minimal side effects; an ideal property of a good anticancer drug (Table 3 ). In addition, these complexes have octahedral coordination geometry with respect to the Ru(III) metal center; however, they exhibit different biological activities despite their structural and chemical similarities. ${ }^{19}$

Recently, 2,2,6,6-tetramethylpiperidine-1-oxyl radical (TEMPO)-functionalized Ru(II) polypyridyl complexes were screened for their efficiency as theranostic photosensitizers for cancer treatment. ${ }^{21}$ The presence of a redox-sensitive TEMPO moiety enhanced the intracellular fluorescence of TEMPOfunctionalized $\mathrm{Ru}$ (II) complexes in photodynamic treatment, which was observed using confocal microscopy and flow cytometry. Hence, the combination of TEMPO with photosensitizers is a promising strategy for the development of novel photosensitizer-based theranostic platforms, which can induce and monitor photodynamic therapy responses simultaneously. In another study, Gill et al demonstrated that the $\mathrm{Ru}(\mathrm{II})$ polypyridyl complex $\left[\mathrm{Ru}(\mathrm{dppz})_{2}(\mathrm{PIP})\right]^{2+}$ intercalates DNA and acts to stall replication fork progression in human cancer cells, leading to the activation of DNA replication stress signaling responses and inhibition of cell growth by cell-cycle deregulation. Combination of the Ru complex with a pathway-specific DNA damage response inhibitor resulted in synergistic cancer cell killing. In addition, the Ru complex functions as a radiosensitizer in combination with external beam ionizing radiation. These findings indicate that $\mathrm{Ru}$ polypyridyl complexes (RuPOPs) are useful tools to study the molecular consequences of DNA intercalation. Hence, the potential benefits and application of these complexes in combination therapy for cancer treatment warrants further investigation. ${ }^{22}$

Recently, Koceva-Chyła et al evaluated the in vitro anticancer activity of dinuclear trithiolato-bridged arene ruthenium complex diruthenium-1 (DiRu-1) against a panel of human cancer cell lines including HepG2 (hepatocellular carcinoma), MCF-7 (estrogen-responsive breast adenocarcinoma), and MDA-MB-231 (triple-negative breast adenocarcinoma) cells. DiRu-1 was found to be extremely toxic to these cell lines, with half-maximal inhibitory concentration $\left(\mathrm{IC}_{50}\right)$ values in the low-nanomolar range. The cytotoxic and proapoptotic effects of DiRu-1 were attributed to the increase in intracellular levels of ROS, while the anticancer effect was due to the induction of DNA lesions caused by apoptotic DNA fragmentation and cell-cycle arrest at the $\mathrm{G}_{2} / \mathrm{M}$ checkpoint. ${ }^{23}$ In summary, the diverse modes of action of Ru anticancer drugs likely enhanced their anticancer activities and minimized the potential for cancer cells to 
Table 2 Recent studies on the anticancer mechanisms of various ruthenium $(\mathrm{Ru})$ complexes

\begin{tabular}{|c|c|c|c|}
\hline Serial number & Complex & Mechanism(s) involved & References \\
\hline I & $\begin{array}{l}\text { Ru(II) polypyridyl complexes; } \\
\text { Ru trithiolato complexes; } \\
\text { Ru anthraquinone complexes; } \\
{[\text { Ru(gly)(bipy)(dppb)]PF6 complex; }} \\
\text { Ru ketoconazole and letrazole complexes; } \\
\text { Ru sulfoxide complexes; } \\
\text { indazole Ru complexes }\end{array}$ & Cell-cycle arrest/cell apoptosis/DNA damage & $|6,17,20,4|-44$ \\
\hline 2 & $\begin{array}{l}\text { Ru polypyridyl complexes; } \\
\text { cyclopentadienyl Ru complexes; } \\
\text { Ru hydrazine complexes }\end{array}$ & $\begin{array}{l}\text { Cell apoptosis through ROS-mediated } \\
\text { mitochondrial dysfunction/cell-cycle arrest/ } \\
\text { DNA damage }\end{array}$ & $40,45,46$ \\
\hline 3 & $\begin{array}{l}\text { Ru(II) complexes: } \\
{[\mathrm{Ru}(\mathrm{dtzp})(\mathrm{dppz}) \mathrm{Cl}]^{+} \text {and }\left[\mathrm{Ru}(\mathrm{dtzp})(\mathrm{dppz}) \mathrm{CH}_{3} \mathrm{CN}\right]^{2+} \text {; }} \\
\text { Ru phthalocyanine complexes }\end{array}$ & Photocytotoxic/cell proliferation/cell apoptosis & $47-49$ \\
\hline 4 & Ru arene complexes & $\begin{array}{l}\text { Interaction with DNA via intercalation of the } \\
\text { aromatic ligand between base pairs }\end{array}$ & 50 \\
\hline 5 & Ru nitrosyl complexes & Nitric oxide release mediated by redox reaction & 51 \\
\hline 6 & Ru carbene complexes & Transmembrane carrier/DNA damage & 52 \\
\hline 7 & $\begin{array}{l}\text { Thiazolo arene Ru complex; } \\
\text { Ru bistridentate complexes; } \\
\text { Ru carbonyl complexes; } \\
\text { Ru pyrazole complexes; } \\
\text { Ru half sandwich complexes; } \\
\text { Ru terpyridine complexes; } \\
\text { Ru bridged complexes; } \\
\text { Ru pterin complexes; } \\
\text { cyclometalated Ru complexes; } \\
\text { Ru sandwich complexes; } \\
\text { Ru-letrazole complexes; } \\
\text { Bis(allyl)-Ru complexes; } \\
\text { dihydro phenazine Ru complexes; } \\
\text { Ru curcuminoid complexes }\end{array}$ & Cell proliferation/cell apoptosis/DNA damage & $\mathrm{I}, 20,45,53-67$ \\
\hline 8 & Dinuclear Ru complexes & Cytoplasmic membrane damage & 68 \\
\hline 9 & Ru chalcone complexes & DNA fragmentation/cell-cycle arrest & 69 \\
\hline 10 & Ru carboline complexes & $\begin{array}{l}\text { Cell proliferation/mitochondrial pathway } \\
\text { dysfunction/inhibition of CDKI and CYCLIN } \\
\text { BI/ROS generation/cell-cycle arrest }\end{array}$ & 70,71 \\
\hline 11 & Ru arene Schiff base complexes & $\begin{array}{l}\text { Apoptosis via induction of } \mathrm{p} 53 \text {-independent } \\
\text { mechanism }\end{array}$ & 72 \\
\hline 12 & Ru pyridine complexes & $\begin{array}{l}\text { Induction of apoptosis via suppression } \\
\text { of vascular endothelial growth factor, } \\
\text { metalloproteinases } 2 \text { and } 9 \text { (MMP-2 and -9) }\end{array}$ & 73 \\
\hline 13 & Ru polypyridine complexes & ROS-induced cell death/DNA damage & 74 \\
\hline 14 & Ru quinaldamide complexes & $\begin{array}{l}\text { Inhibition of thioredoxin reductase I (Trx-R)- } \\
\text { induced cell death/cell apoptosis }\end{array}$ & 75 \\
\hline 15 & Ru N-heterocyclic carbene complexes & $\begin{array}{l}\text { Induction of cell death via activation of apoptosis } \\
\text { signal-regulating kinase I pathway/inhibition of } \\
\text { Trx-R-induced cell death }\end{array}$ & 76 \\
\hline 16 & Ru arene Schiff base and Ru-aniline complexes & $\begin{array}{l}\text { Apoptosis via induction of p53-independent } \\
\text { mechanism and suppression of vascular } \\
\text { endothelial growth factor }\end{array}$ & $72,77,78$ \\
\hline 17 & Chiral Ru complexes & Inhibition of topoisomerase-II/DNA damage & 79 \\
\hline 18 & Diene Ru complexes & $\begin{array}{l}\text { Mitochondrial pathway dysfunction/cell } \\
\text { apoptosis }\end{array}$ & 80 \\
\hline 19 & Bidentate Schiff base Ru complexes & DNA cleavage/DNA damage & 81 \\
\hline 20 & $\begin{array}{l}\text { Flavanol-derived ligand Ru complexes; } \\
\mathrm{Ru}(\mathrm{II}) \text {-DMSO-chalcone complexes }\end{array}$ & $\begin{array}{l}\text { Inhibition of topoisomerase II and CDK2/DNA } \\
\text { damage/cell proliferation }\end{array}$ & $82-84$ \\
\hline 21 & Di- and tricarbonyl Ru complexes & Cell proliferation/cell apoptosis & 85 \\
\hline
\end{tabular}

Abbreviations: DMSO, Dimethyl sulfoxide; ROS, reactive oxygen species. 
Table 3 Antitumor mechanisms of ruthenium $(\mathrm{Ru})$ complexes which are under Phase Il clinical trials

\begin{tabular}{|c|c|c|c|c|}
\hline Serial number & Ru complex & Chemical structure & Mechanism involved & References \\
\hline I & $\begin{array}{l}\text { NAMI-A } \\
\text { (imidazolium [trans- } \\
\text { tetrachloro(DMSO)(imidazole) } \\
\text { ruthenate(III)]) }\end{array}$ & & $\begin{array}{l}\text { Interferes with the interaction between tumor } \\
\text { cells and the extracellular matrix by increasing } \\
\text { actin-dependent cell adhesion and reducing cell } \\
\text { invasiveness and migration }\end{array}$ & 86,87 \\
\hline 2 & $\begin{array}{l}\text { KPIOI9 } \\
\text { (indazolium [trans- } \\
\text { tetrachlorobis(IH-indazole) } \\
\text { ruthenate(III)]) }\end{array}$ & & $\begin{array}{l}\text { Disruption of the cellular redox balance, } \\
\text { followed by induction of } G_{2} / M \text { cell-cycle } \\
\text { arrest, blockage of DNA synthesis, and } \\
\text { induction of apoptosis via the mitochondrial } \\
\text { pathway }\end{array}$ & 88 \\
\hline 3 & $\begin{array}{l}\text { NPK-I } 339 \\
\text { (sodium trans- } \\
\text { [tetrachloridobis(IH-indazole) } \\
\text { ruthenate(III)]) }\end{array}$ & & $\begin{array}{l}\text { Disruption of the cellular redox balance, } \\
\text { followed by induction of } \mathrm{G}_{2} / \mathrm{M} \text { cell-cycle } \\
\text { arrest, blockage of DNA synthesis, and } \\
\text { induction of apoptosis via the mitochondrial } \\
\text { pathway }\end{array}$ & 89 \\
\hline
\end{tabular}

develop resistance against these drugs. ${ }^{24}$ Novel approaches to metabolic studies are required to give additional mechanistic insights, which could lead to the rational design of better $\mathrm{Ru}$ anticancer drugs.

Despite solving many key issues encountered with conventional anticancer therapies such as chemotherapy, systemic delivery of nanoparticles faces several of its own challenges, one of which is the lack of successful tumor localization. Among the various strategies, nanostructured materials functionalized with metal complexes have attracted the most interest among oncologists and medicinal chemists as a better alternative for administration of metallodrugs in targeted anticancer therapy. ${ }^{9}$ In addition, the encapsulation and delivery of metallodrugs in nanostructures have overcome the problems of poor bioavailability, degradation, and side effects. ${ }^{25}$

\section{Importance of nanostructured materials functionalized with metal complexes in cancer treatment}

Nanotechnology currently allows for a unique control of the material world, and any material comprising an average phase or grain size in the order of a nanometer $\left(10^{-9} \mathrm{~m}\right)$ is defined as a nanostructured material. At this scale, man-made objects are able to gain access to cells as nanostructured materials have enhanced mechanical properties compared to conventional materials due to their ultrafine microstructure and ability to interface with living cells. Nanostructured materials of varying compositions play important roles in cancer therapeutics due to their passive tumor targeting property. ${ }^{26,27}$ In this context, inorganic metal complexes occupy a pioneer niche as they offer a multipurpose platform for drug design and development, and the nanostructures used in the functionalization of metallodrugs act as transport vehicles to deliver the metallodrugs to the biological target. Nanostructured systems, such as macromolecular systems, carbon nanotubes, dendrimers, metallacages, ceramic materials, liposomes, and lipid nanocapsules, as well as metal and polymeric nanoparticles are commonly used for drug delivery. In addition, the optimum loading and sustained release of metallodrugs from nanostructures are essential requirements for every drug delivery system. Therefore, it is important to ensure that metallodrugs are attached to the surface of nanoparticles with adequate strength to withstand the wear and tear during the passage to the target site. However, it is also crucial to ensure that the bond is weak enough to release the metallodrugs at the target site. ${ }^{9}$

In a study conducted by $\mathrm{Wu}$ et al, gold nanoparticles (AuNPs) were shown to be efficient carriers for small interfering RNA (siRNA) delivery into cancer cells. In this study, cysteamine-functionalized AuNPs were found to effectively deliver transforming growth factor beta 1 (TGF- $\beta 1$ ) siRNA 
into hepatoma HepG2 cells, and compared with AuNPmediated nano carrier (NC) siRNA (AuNP-siNC), AuNPdelivered TGF- $\beta 1$ siRNA (AuNP-siTGF $\beta 1$ ) successfully decreased the level of TGF- $\beta 1$, increased cell apoptosis, and significantly inhibited the proliferation of recipient tumor cells. Likewise, systemic administration of AuNP-siTGF $\beta 1$ complexes into human HepG2 xenografted mice reduced TGF- $\beta 1$ expression and its downstream signaling. Functionally, AuNP-siTGF $\beta 1$ strongly inhibited tumor growth and improved the survival rate of tumor-bearing mice compared with the control group. These results suggest that AuNP is a highly effective method for delivering RNA interference therapeutics into tumor cells. ${ }^{28}$ In another study, titanium dioxide $\left(\mathrm{TiO}_{2}\right)$ was functionally modified with amine, sulfate, and phosphate ions into the biocompatible titania $\left(\mathrm{F}-\mathrm{TiO}_{2}\right)$. Due to the porous nature of $\mathrm{F}-\mathrm{TiO}_{2}$, it can trap drugs into its cavity, allowing it to be used as a nanocarrier. $\mathrm{F}-\mathrm{TiO}_{2}$ showed little to no toxicity when tested at various concentrations in several cancer cell lines, with $<10 \%$ cell death. These results suggest that $\mathrm{F}-\mathrm{TiO}_{2}$ can be used as a nanostructured carrier to deliver drugs effectively and safely by functionally modifying the surface to increase its affinity toward acidic environment (tumor), thus minimizing toxicity and accumulation in normal cells and tissues. ${ }^{29}$

\section{Recent developments in nanostructured materials functionalized with Ru complexes for targeted drug delivery}

In recent years, $\mathrm{Ru}$ complexes have attracted much attention as an alternative to existing platinum drugs, showing remarkable antitumoral and antimetastatic activities with low toxicity. ${ }^{30,31}$ However, one of the foremost drawbacks of $\mathrm{Ru}$ complexes is their rather limited stability in aqueous solutions. Therefore, designing long-life Ru-based antineoplastic agents is the primary goal to overcome this limitation, and nanostructured materials functionalized with $\mathrm{Ru}$ complexes serve as one of the alternatives for targeted drug delivery. ${ }^{32-35}$ A recent study by Huang et al showed that the antitumor efficacy of RuPOPs could be enhanced by using cancer-targeted DNA origami as a biocompatible nanocarrier. Under this condition, the formation of unique tetrahedral nanostructure of DNA cages effectively enhanced the partial intercalation of RuPOP, thus increasing the drug-loading efficacy. In addition, conjugation of biotin to the DNA-based nanosystem (Bio-cage $@$ Ru) enhanced its specific cellular uptake, drug retention, and cytotoxicity against HepG2 cells. Unlike free RuPOP and the cage itself, Bio-cage@Ru is translocated to the cell nucleus after internalization, where it undergoes self-immolative cleavage in response to DNases, triggering drug release, and inducing ROS-mediated cell apoptosis. In the nude mouse model, this nanosystem exhibited satisfactory in vivo antitumor efficacy as it specifically accumulated in tumor sites and alleviated RuPOP and tumor xenograft-induced damages to the liver, kidney, lung, and heart function. Therefore, this study demonstrates a strategy for the development of biocompatible and cancer-targeted DNA origami with enhanced anticancer efficacy and reduced toxicity for next-generation cancer therapy. ${ }^{32}$

A novel $\mathrm{pH}$-sensitive nanocapsule was recently shown to effectively deliver tris(1,10-phenanthroline) $\mathrm{Ru}(\mathrm{II})$ complex $(3 \mathrm{P}-\mathrm{Ru})$ into glioma cells. In this study, delivery of $3 \mathrm{P}-\mathrm{Ru}$ using the $\mathrm{pH}$-sensitive nanocarrier significantly inhibited cell growth in both in vitro and in vivo models. The nanocapsule-induced cell death was mediated in part through the induction of apoptosis. As such, this novel tumor targeting approach holds great potential for theranostics applications. ${ }^{33}$ In another study, a pH-sensitive mesoporous silica nanocarrier, RuNHC@MSNs-chitosan-biotin, was synthesized for the targeted delivery and controlled release of a $\mathrm{Ru}(\mathrm{II})$ N-heterocyclic carbene (RuNHC) complex. The authors demonstrated that the complex is selectively internalized by cancer cells through biotin receptor-mediated endocytosis, which enhanced its anticancer activities. Hence, this approach offers a platform for the development of accurately controlled cancer therapy. ${ }^{34}$ In another study, a dual-fluorescent nanocarrier was synthesized by coating human serum albumin on $\mathrm{Ru}$ complex-loaded lanthanide-doped upconversion nanoparticles to generate $\mathrm{Ru}$-human serum albumin-upconversion nanoparticles. Interestingly, this conjugate showed very low inhibitory effect on cell proliferation in the dark, whereas light irradiation considerably improved its cytotoxicity toward cancer cells. In addition, irradiation activated this Ru complex and the product became highly reactive to DNA. The obtained results suggest the potential application of this conjugate in the controlled release of active anticancer agents in tumor sites. ${ }^{35}$ Recently, two novel Ru metalloarenes were synthesized based on anthracene units, and both compounds showed high cytotoxicity against HL-60 cancer cell line, mediated by the induction of apoptosis. In addition, these Ru metallodrugs were successfully encapsulated into two well-known biocompatible and stable mesoporous silicas (MCM-41 and SBA-15) using impregnation and grinding strategies. ${ }^{36}$ In a study, Xue et al developed a supramolecular approach that assembles a $\beta$-cyclodextrin (CD)-functionalized Ru(II) polypyridyl complex with an adamantane-appended tumor-targeting cyclic 
Table 4 List of nanostructured materials functionalized with ruthenium (Ru) complexes for targeted drug delivery

\begin{tabular}{|c|c|c|c|c|}
\hline No & Nanostructured material & Ru complex & Target & References \\
\hline 1 & $\begin{array}{l}\text { Tetrahedral nanostructure of DNA } \\
\text { (height } 2.0 \mathrm{~nm} \text {; size } 33.5 \mathrm{~nm} \text { ) }\end{array}$ & Ru polypyridyl complex & $\begin{array}{l}\text { ROS-mediated cell apoptosis (human liver } \\
\text { carcinoma cells) }\end{array}$ & 33 \\
\hline 2 & $\begin{array}{l}\text { The core/shell structured nanocapsule } \\
(\text { size } 103.1 \pm 11.3 \mathrm{~nm})\end{array}$ & $\begin{array}{l}\text { Ru complex tris(I,I0-phenanthroline) } \\
\text { Ru(II) complex (3P-Ru) }\end{array}$ & Inhibition of cell growth (glioma cells) & 34 \\
\hline 3 & $\begin{array}{l}\mathrm{pH} \text {-sensitive mesoporous silica } \\
\text { nanocarrier (MSN) (size } 90 \mathrm{~nm})\end{array}$ & $\begin{array}{l}\text { Ru(II) N-heterocyclic carbine complex } \\
\text { (RuNHC) coated with chitosan biotin }\end{array}$ & $\begin{array}{l}\text { Selectivity of RuNHC between cancer and } \\
\text { normal cells. The biotin on the surface of the } \\
\text { drug-loaded nanoparticles mediated higher } \\
\text { accumulation in cancer cells }\end{array}$ & 35 \\
\hline 4 & $\begin{array}{l}\text { Lanthanide-doped up-conversion } \\
\text { nanoparticles coated with human } \\
\text { serum albumin (size 60-120 nm) }\end{array}$ & $\begin{array}{l}\text { A photo-sensitive Ru complex, } \\
{\left[\mathrm{Ru}(\mathrm{bpy})_{2}(\mathrm{dmbpy})\right] \mathrm{Cl}_{2}}\end{array}$ & $\begin{array}{l}\text { Controlled release of active anticancer } \\
\text { agents in tumor sites }\end{array}$ & 36 \\
\hline 5 & $\begin{array}{l}\text { Inorganic mesoporous silicas } \\
(\text { size } 40 \mathrm{~nm})\end{array}$ & $\begin{array}{l}\text { Anthracene-based half-sandwich } \\
\text { organometallic Ru(II) compounds }\end{array}$ & $\begin{array}{l}\text { Cytotoxic activity toward leukemia cells } \\
(\mathrm{HL}-60) \text { via apoptosis }\end{array}$ & 37 \\
\hline 6 & $\begin{array}{l}\text { Self-assembled supramolecular } \\
\text { nanoparticles (height } 1.5 \mathrm{~nm} \text {; } \\
\text { size } 30-50 \mathrm{~nm} \text { ) }\end{array}$ & $\begin{array}{l}\beta \text {-Cyclodextrin-functionalized Ru(II) } \\
\text { polypyridyl complex }\end{array}$ & $\begin{array}{l}\text { Controlled drug release and induce cell } \\
\text { death in integrin } \alpha v \beta 3 \text {-rich tumor cells }\end{array}$ & 38 \\
\hline 7 & $\begin{array}{l}\text { Single-walled carbon nanotemplates } \\
\text { (size ranged from } 20 \mathrm{~nm} \text { ) }\end{array}$ & $\mathrm{Ru}(\mathrm{II})$ complexes & Photothermally triggered release & 39 \\
\hline 8 & $\begin{array}{l}\text { Functionalized multiwalled carbon } \\
\text { nanotubes as carriers (the average } \\
\text { diameter is } 224.9 \mathrm{~nm} \text { ) }\end{array}$ & Ru polypyridyl complex (RuPOP) & $\begin{array}{l}\text { Induction of cell death by activation of } \\
\text { downstream signaling pathways, including } \\
\text { DNA damage-mediated p53 phosphorylation, } \\
\text { activation of p38, and inactivation of AKT } \\
\text { and ERK }\end{array}$ & 40 \\
\hline
\end{tabular}

Abbreviation: ROS, reactive oxygen species.

Arg-Gly-Asp c(RGDyK) peptide. In this study, the host-guest system formed stable phosphorescent nanostructures with quantitative drug loading. Consequently, the formed nanoparticles Ru-CD-RGD display high selectivity for integrin $\alpha v \beta 3$-rich human glioblastoma (U87MG) cancer cells over integrin $\alpha v \beta 3$-deficient cancer cells. Mechanistic studies show that Ru-CD-RGD can induce apoptotic cell death through lysosomal damage, ROS elevation, and caspase activation. ${ }^{37}$ In another study, $\mathrm{Ru}$ (II) complex-functionalized single-walled carbon nanotubes were synthesized as nanotemplates for bimodal photothermal and two-photon photodynamic therapy. Here, the synthesized single-walled carbon nanotubes have the ability to load a large quantity of $\mathrm{Ru}(\mathrm{II})$ complexes via noncovalent $\pi-\pi$ interactions. In addition, the loaded $\mathrm{Ru}$ (II) complexes are competently released by the photothermal effect of irradiation. The released $\mathrm{Ru}(\mathrm{II})$ complexes produce singlet oxygen species $\left({ }^{1} \mathrm{O}_{2}\right)$ upon two-photon laser irradiation and can be used as a two-photon photodynamic therapy agent. Based on the combination of photothermal therapy and two-photon photodynamic therapy, Ru@ single-walled carbon nanotubes have greater anticancer efficacies than either photodynamic therapy using $\mathrm{Ru}(\mathrm{II})$ complexes or photothermal therapy using single-walled carbon nanotubes in two-dimensional cancer cell and three-dimensional multicellular tumor spheroid models. ${ }^{38}$ In a study by Wang et al, a carbon nanotube-based radiosensitive drug delivery system was developed to provoke the multidrug resistance in hepatocellular carcinoma. Here, the nanosystem was loaded with RuPOP via $\pi-\pi$ interaction and the formation of a hydrogen bond. The functionalized nanosystem enhanced the cellular uptake of RuPOP in liver cancer cells, particularly drug-resistant human hepatoma cell line, through endocytosis. ${ }^{39} \mathrm{~A}$ list of nanostructured materials functionalized with Ru complexes for targeted drug delivery are summarized in Table 4.

In addition to the above-mentioned findings, the miniaturization of metal-organic frameworks (MOFs) has generated great interest among researchers to integrate these materials into various applications such as sensing or drug delivery. Zhang et al demonstrated that Ru complexes combined with MOFs exhibited effective two-photon adsorption for singlet oxygen $\left({ }^{1} \mathrm{O}_{2}\right)$ generation. They successfully synthesized a novel heterogeneous ${ }^{1} \mathrm{O}_{2}$ generation system, which may prove helpful in photodynamic therapy and chemotherapy integrative collaboration for cancer treatment. ${ }^{40}$

\section{Future prospective and conclusion}

Functionalization of metallodrugs into nanostructures is an increasing area of research, and more groundbreaking advances are expected to be made in the future. Nanostructured $\mathrm{Ru}$ complexes can be used to enhance the efficacy of cancer treatment by targeted delivery of drugs or genes into cancer cells and reduce the adverse effects and systemic 
toxicity by optimization of the pharmacokinetics property of these complexes. Although nanostructured materials functionalized with $\mathrm{Ru}$ complexes have shown great potential in the treatment of cancer, there are still many challenges in translating basic research into clinical applications. Therefore, the most promising area in this field is the development of functionalized nanostructured metal complex drug delivery systems for controlled release, which can greatly improve the activity of complexes without causing any severe adverse effects. In spite of their wide application in cancer chemotherapy, the vehicular nanostructures are toxic to both humans and the environment. As a result, there is an urgent need to thoroughly study the pharmacokinetic behaviors of different types of nanoparticles both in vivo and in vitro.

\section{Acknowledgments}

This research was supported by the R\&D Program for Society of the National Research Foundation (NRF) funded by the Ministry of Science, ICT \& Future Planning (2015M3A9E2031372).

\section{Disclosure}

The authors report no conflicts of interest in this work.

\section{References}

1. Grozav A, Miclaus V, Vostinaru O, et al. Acute toxicity evaluation of a thiazolo arene ruthenium (II) complex in rats. Regul Toxicol Pharmacol. 2016;80:233-240.

2. Gambino D, Otero L. Perspectives on what ruthenium-based compounds could offer in the development of potential antiparasitic drugs. Inorganica Chim Acta. 2012;393:103-114.

3. Vidimar V, Meng X, Klajner M, et al. Induction of caspase 8 and reactive oxygen species by ruthenium-derived anticancer compounds with improved water solubility and cytotoxicity. Biochem Pharmacol. 2012;84(11):1428-1436.

4. Mohanraj M, Ayyannan G, Raja G, Jayabalakrishnan C. Evaluation of DNA binding, DNA cleavage, protein binding, radical scavenging and in vitro cytotoxic activities of ruthenium(II) complexes containing 2,4-dihydroxy benzylidene ligands. Mater Sci Eng C Mater Biol Appl. 2016;69:1297-1306.

5. Allardyce CS, Dyson PJ. Ruthenium in medicine: current clinical uses and future prospects. Platinum Metals Rev. 2001;45(2):62-69.

6. Ude Z, Romero-Canelón I, Twamley B, Fitzgerald Hughes D, Sadler PJ, Marmion CJ. A novel dual-functioning ruthenium (II)-arene complex of an anti-microbial ciprofloxacin derivative - anti-proliferative and anti-microbial activity. J Inorg Biochem. 2016;160:210-217.

7. Liu W, Gust R. Update on metal N-heterocyclic carbene complexes as potential anti-tumor metallodrugs. Coord Chem Rev. 2016;329: 191-213.

8. Mari C, Pierroz V, Ferrari S, Gasser G. Combination of Ru(II) complexes and light: new frontiers in cancer therapy. Chem Sci. 2015;6: 2660-2686.

9. Wani WA, Prashar S, Shreaz S, Gomez-Ruiz S. Nanostructured materials functionalized with metal complexes: in search of alternatives for administering anticancer metallodrugs. Coord Chem Rev. 2016; 312:67-98.

10. Viswanath B, Kim S. Recent insights into the development of nanotechnology to detect circulating tumor cells. Trends Analyt Chem. 2016;82: 191-198.
11. León IE, Cadavid-Vargas JF, Di Virgilio AL, Etcheverry S. Vanadium, ruthenium and copper compounds: a new class of non-platinum metallodrugs with anticancer activity. Curr Med Chem. 2016;24(2): $112-148$.

12. Haas KL, Franz KJ. Application of metal coordination chemistry to explore and manipulate cell biology. Chem Rev. 2009;109:4921-4960.

13. Frezza M, Hindo S, Chen D, et al. Novel metals and metal complexes as platforms for cancer therapy. Curr Pharm Des. 2010;16(16): 1813-1825.

14. Li F, Collins JG, Keene FR. Ruthenium complexes as antimicrobial agents. Chem Soc Rev. 2015;44(8):2529-2542.

15. Colina-Vegas L, Dutra JL, Villarreal W, et al. Ru(II)/clotrimazole/ diphenylphosphine/bipyridine complexes: interaction with DNA, BSA and biological potential against tumor cell lines and Mycobacterium tuberculosis. J Inorg Biochem. 2016;162:135-145.

16. Dragutan I, Dragutan V, Demonceau A. Editorial of special issue ruthenium complex: the expanding chemistry of the ruthenium complexes. Molecules. 2015;20(9):17244-17274.

17. Chen JC, Li GD, Peng F, et al. Investigation of inducing apoptosis in human lung cancer A549 cells and related mechanism of a ruthenium (II) polypyridyl complex. Inorg Chem Commun. 2016;69:35-39.

18. Lima AP, Pereira FC, Almeida MA, et al. Cytoxicity and apoptotic mechanism of ruthenium(II) amino acid complexes in sarcoma-180 tumor cells. PLoS One. 2014;9(10):e105865.

19. Motswainyana WM, Ajibade PA. Anticancer activities of mononuclear ruthenium (II) coordination complexes. Adv Chem. 2015; 2015:859730

20. Furrer J, Süss-Fink GS. Thiolato-bridged dinuclear arene ruthenium complexes and their potential as anticancer drugs. Coord Chem Rev. 2016;309:36-50.

21. Yang J, Cao Q, Hu WL, et al. Theranostic TEMPO-functionalized Ru(ii) complexes as photosensitizers and oxidative stress indicators. Dalton Trans. 2017;46(2):445-454.

22. Gill MR, Harun SN, Halder S, et al. A ruthenium polypyridyl intercalator stalls DNA replication forks, radiosensitizes human cancer cells and is enhanced by Chk1 inhibition. Sci Rep. 2016;6:31973.

23. Koceva-Chyła A, Matczak K, Hikisz MP, et al. Insights into the in vitro anticancer effects of Diruthenium-1. Chem Med Chem. 2016; 11(19):2171-2187.

24. Levina A1, Mitra A, Lay PA. Recent developments in ruthenium anticancer drugs. Metallomics. 2009;1(6):458-470.

25. Rehman HU, Freitas TF, Gomes RN, Colquhoun A, de Oliveria Silva D. Axially-modified paddlewheel diruthenium(II,III)-ibuprofenato metallodrugs and the influence of the structural modification on U87MG and A172 human glioma cell proliferation, apoptosis, mitosis and migration. J Inorg Biochem. 2016;165:181-191.

26. Bae KH, Chung HJ, Park TG. Nanomaterials for cancer therapy and imaging. Mol Cells. 2011;31(4):295-302.

27. Mohamed NK, Hamad MA, Hafez MZ, Wooley KL, Elsabahy M. Nanomedicine in management of hepatocellular carcinoma: challenges and opportunities. Int J Cancer. 2016;140:1475-1484.

28. Wu J, Liu B, Wu H, et al. A gold nanoparticle platform for the delivery of functional TGF- $\beta 1$ siRNA into cancer cells. J Biomed Nanotechnol. 2016;12(4):800-810.

29. Lopez T, Ortiz E, Guevara P, Gómez E, Novaro O. Physicochemical characterization of functionalized-nanostructured-titania as a carrier of copper complexes for cancer treatment. Mater Chem Phys. 2014: 146(1):37-49.

30. Scintilla S, Brustolin L, Gambalunga A, et al. Ru(III) anticancer agents with aromatic and non-aromatic dithiocarbamates as ligands: loading into nanocarriers and preliminary biological studies. J Inorg Biochem. 2016;166:76-86.

31. Dömötör O, de Almeida RFM, Côrte-Real L, et al. Studies on the mechanism of action of antitumor bis(aminophenolate) ruthenium(III) complexes. J Inorg Biochem. 2017;168:27-37.

32. Huang Y, Huang W, Chan L, Zhou B, Chen T. A multifunctional DNA origami as carrier of metal complexes to achieve enhanced tumoral delivery and nullified systemic toxicity. Biomaterials. 2016;103:183-196. 
33. Chen L, Fu C, Deng Y, Wu W, Fu A. A pH-sensitive nanocarrier for tumor targeting: delivery of ruthenium complex for tumor theranostic by $\mathrm{pH}$-sensitive nanocapsule. Pharm Res. 2016;33(12):2989-2998.

34. Lv G, Qiu L, Liu G, et al. pH sensitive chitosan-mesoporous silica nanoparticles for targeted delivery of a ruthenium complex with enhanced anticancer effects. Dalton Trans. 2016;45(45):18147-18155.

35. Shi H, Fang T, Tian Y, Huang H, Liu Y. A dual-fluorescent nano-carrier for delivering photoactive ruthenium polypyridyl complexes. J Mater Chem B. 2016;4:4746.

36. Rojas S, Carmona FJ, Barea E, Maldonado CR. Inorganic mesoporous silicas as vehicles of two novel anthracene-based ruthenium metalloarenes. J Inorg Biochem. 2017;166:87-93.

37. Xue SS, Tan CP, Chen MH, et al. Tumor-targeted supramolecular nanoparticles self-assembled from a ruthenium- $\beta$-cyclodextrin complex and an adamantane-functionalized peptide. Chem Commun (Camb). 2017;53(5):842-845.

38. Zhang $\mathrm{P}$, Huang $\mathrm{H}$, Huang J, et al. Noncovalent ruthenium (II) complexes-single-walled carbon nanotube composites for bimoda photothermal and photodynamic therapy with near-infrared irradiation ACS Appl Mater Interfaces. 2015;7:23278-23290.

39. Wang N, Feng Y, Zeng L, Zhao Z, Chen T. Functionalized multiwalled carbon nanotubes as carriers of ruthenium complexes to antagonize cancer multidrug resistance and radioresistance. ACS Appl Mater Interfaces. 2015;7:14933-14945.

40. Zhang W, Li B, Ma H, et al. Combining ruthenium(II) complexes with metal-organic frameworks to realize effective two-photon absorption for singlet oxygen generation. ACS Appl Mater Interfaces. 2016;8(33):21465-21471.

41. Wang JQ, Zhao ZZ, Bo HB, Chen QZ. Synthesis, characterization, and antitumor properties of ruthenium (II) anthraquinone complexes. J Coord Chem. 2016;69:177-189.

42. Robles-Escajeda E, Martínez A, Varela-RamirezA, Sánchez-Delgado RA, Aguilera RJ. Analysis of the cytotoxic effects of ruthenium-ketoconazole and ruthenium-clotrimazole complexes on cancer cells. Cell Biol Toxicol. 2013;29(6):431-443.

43. Bytzek AK, Koellensperger G, Keppler BK, Hartinger CG. Biodistribution of the novel anticancer drug sodium trans-[tetrachloridobis (1H-indazole) ruthenate (III)] KP-1339/IT139 in nude BALB/c mice and implications on its mode of action. J Inorg Biochem. 2016; 160:250-255.

44. Jovanovic KK, Gligorijevic N, Gaur R, Mishra L, Radulovic S. Anticancer activity of two ruthenium (II)-DMSO-chalcone complexes: comparison of cytotoxic, pro-apoptotic and antimetastatic potential J BUON. 2015;21:482-490.

45. Morais TS, Silva TJ, Marques F, et al. Synthesis of organometallic ruthenium (II) complexes with strong activity against several human cancer cell lines. J Inorg Biochem. 2012;114:65-74.

46. Jayanthi E, Kalaiselvi S, Padma VV, Bhuvanesh NS, Dharmaraj N. Solvent assisted formation of ruthenium (III) and ruthenium (II) hydrazone complexes in one-pot with potential in vitro cytotoxicity and enhanced LDH, NO and ROS release. Dalton Trans. 2016;45(4):1693-1707.

47. Yu HJ, Liu JP, Hao ZF, et al. Synthesis, characterization and biological evaluation of ruthenium (II) complexes [Ru (dtzp)(dppz) $\mathrm{Cl}]+$ and [Ru (dtzp)(dppz) CH $3 \mathrm{CN}] 2+$ for photodynamic therapy. Dyes Pigm. 2017;136:416-426.

48. Zhang C, Zeng CC, Lai SH, et al. Synthesis, cytotoxicity in vitro, apoptosis, cell cycle arrest and comet assay of asymmetry ruthenium (II) complexes. Polyhedron. 2016;106:115-124.

49. Heinrich TA, Tedesco AC, Fukuto JM, da Silva RS. Production of reactive oxygen and nitrogen species by light irradiation of a nitrosyl phthalocyanine ruthenium complex as a strategy for cancer treatment. Dalton Trans. 2014;43:4021-4025.

50. Miserachs HG, Cipriani M, Grau J, et al. Antitumor and antiparasitic activity of novel ruthenium compounds with polycyclic aromatic ligands. J Inorg Biochem. 2015;150:38-47.

51. Carneiro ZA, Biazzotto JC, Alexiou AD, Nikolaou S. Nitric oxide photorelease from a trinuclear ruthenium nitrosyl complex and its in vitro cytotoxicity against melanoma cells. J Inorg Biochem. 2014;134:36-38.
52. Schmitt F, Donnelly K, Muenzner JK, et al. Effects of histidin-2-ylidene vs. imidazol-2-ylidene ligands on the anticancer and antivascular activity of complexes of ruthenium, iridium, platinum, and gold. J Inorg Biochem. 2016;163:221-228.

53. Kuhn PS, Meier SM, Jovanović KK, et al. Ruthenium carbonyl complexes with azole heterocycles-synthesis, X-ray diffraction structures, DFT calculations, solution behavior, and antiproliferative activity. Eur J Inorg Chem. 2016;2016(10):1566-1576.

54. David S, Perkins RS, Fronczek FR, Kasiri S, Mandal SS, Srivastava RS. Synthesis, characterization, and anticancer activity of rutheniumpyrazole complexes. J Inorg Biochem. 2012;111:33-39.

55. Kamatchi TS, Kalaivani P, Fronczek FR, Natarajan K, Prabhakaran R. Impact of chelation on anticancer activities of organometallic ruthenium (ii) complexes containing 2, 5-di (1 H-pyrazol-1-yl)-1, 4-benzoquinone: synthesis, structure, DNA/protein binding, antioxidant activity and cytotoxicity. RSC Adv. 2016;6:46531-46547.

56. Mehta JV, Gajera SB, Patel MN. Biological applications of pyrazolinebased half-sandwich ruthenium (III) coordination compounds. J Biomol Struct Dyn. 2016;16:1-9.

57. Lazić D, Arsenijević A, Puchta R, Bugarčić ŽD, Rilak A. DNA binding properties, histidine interaction and cytotoxicity studies of water soluble ruthenium (II) terpyridine complexes. Dalton Trans. 2016; 45(11):4633-4646.

58. Lord RM, Allison SJ, Rafferty K, Ghandhi L, Pask CM, McGowan PC. Cytotoxic hydrogen bridged ruthenium quinaldamide complexes showing induced cancer cell death by apoptosis. Dalton Trans. 2016; 45(33):13196-13203.

59. Dalton SR, Glazier S, Leung B, Win S, Megatulski C, Burgmayer SJ. DNA binding by Ru (II)-bis (bipyridine)-pteridinyl complexes. J Inorg Biochem. 2008;13:1133-1148.

60. Huang H, Zhang P, Chen H, Ji L, Chao H. Comparison between polypyridyl and cyclometalated ruthenium (II) complexes: anticancer activities against 2D and 3D cancer models. Chemistry. 2015;21:715-725.

61. Gupta G, Oggu GS, Nagesh N, Bokara KK, Therrien B. Anticancer activity of large metalla-assemblies built from half-sandwich complexes. Cryst Eng Comm. 2016;18:4952-4957.

62. Su W, Tang Z, Li P. Development of arene ruthenium antitumor complexes. Mini Rev Med Chem. 2016;16:787-795.

63. Kaur R, Ranjan Dwivedi A, Kumar B, Kumar V. Recent developments on 1,2,4-triazole nucleus in anticancer compounds: a review. Anticancer Agents Med Chem. 2016;16(4):465-489.

64. Kubanik M, Kandioller W, Kim K, et al. Towards targeting anticancer drugs: ruthenium (ii)-arene complexes with biologically active naphthoquinonederived ligand systems. Dalton Trans. 2016;45:13091-13103.

65. Li G, Sun L, Ji L, Chao H. Ruthenium (ii) complexes with dppz: from molecular photoswitch to biological applications. Dalton Trans. 2016;45:13261-13276.

66. Caruso F, Pettinari R, Rossi M, et al. The in vitro antitumor activity of arene-ruthenium (II) curcuminoid complexes improves when decreasing curcumin polarity. J Inorg Biochem. 2016;162:44-51.

67. Enyedy ÉA, Sija É, Jakusch T, et al. Solution equilibria of anticancer ruthenium (II)-( 7 6-p-cymene)-hydroxy (thio) pyr (id) one complexes: impact of sulfur vs. oxygen donor systems on the speciation and bioactivity. J Inorg Biochem. 2013;127:161-168.

68. Li X, Heimann K, Dinh XT, Keene FR, Collins JG. Biological processing of dinuclear ruthenium complexes in eukaryotic cells. Mol BioSyst. 2016;12(10):3032-3045.

69. Singh AK, Saxena G, Dixit S, et al. Synthesis, characterization and biological activities of some Ru (II) complexes with substituted chalcones and their applications as chemotherapeutics against breast cancer. J Mol Struct. 2016;1111:90-99.

70. Chen Y, Qin MY, Wu JH, et al. Synthesis, characterization, and anticancer activity of ruthenium (II)- $\beta$-carboline complex. Eur J Med Chem. 2013;70:120-129.

71. He L, Liao SY, Tan CP, et al. Ruthenium-arene- $\beta$-carboline complexes as potent inhibitors of cyclin-dependent kinase 1 : synthesis, characterization and anticancer mechanism studies. Chemistry. 2013;19(36): 12152-12160. 
72. Chow MJ, Babak MV, Wong DY, Pastorin G, Gaiddon C, Ang WH. Structural determinants of p53-independence in anticancer rutheniumarene Schiff-base complexes. Mol Pharm. 2016;13(7):2543-2554.

73. Gu L, Li X, Ran Q, Kang C, Lee C, Shen J. Antimetastatic activity of novel ruthenium (III) pyridine complexes. Cancer Med. 2016;5(10): 2850-2860.

74. Mazuryk O, Łomzik M, Martineau D, et al. Anticancer activity of ruthenium (II) polypyridine complexes bearing pyrrolidine substituents. Inorganica Chim Acta. 2016;443:86-90.

75. Almodares Z, Lucas SJ, Crossley BD, et al. Rhodium, iridium, and ruthenium half-sandwich picolinamide complexes as anticancer agents. Inorg Chem. 2014;53(2):727-736.

76. Qian C, Wu J, Ji L, Chao H. Topoisomerase II $\alpha$ poisoning and DNA double-strand breaking by chiral ruthenium (ii) complexes containing 2-furanyl-imidazo [4, 5-f][1, 10] phenanthroline derivatives. Dalton Trans. 2016;45(26):10546-10555.

77. Chow MJ, Licona C, Yuan Qiang Wong D, Pastorin G, Gaiddon C, Ang WH. Discovery and investigation of anticancer ruthenium-arene Schiff-base complexes via water-promoted combinatorial threecomponent assembly. J Med Chem. 2014;57(14):6043-6059.

78. Zhang Y, Zheng W, Luo Q, et al. Dual-targeting organometallic ruthenium (II) anticancer complexes bearing EGFR-inhibiting 4-anilinoquinazoline ligands. Dalton Trans. 2015;44(29):13100-13111.

79. Zhang X, Huang Z, Wu S, Lin R, Liu J, Su N. Investigation of antitumor mechanism of the chiral ruthenium complex $\Lambda$-[Ru (phen) 2 p-MOPIP] $2+$ in human gastric cancer MGC-803 cells. Inorg Chem Commun. 2016; 72:1-6.

80. Kasper C, Alborzinia H, Can S, et al. Synthesis and cellular impact of diene-ruthenium (II) complexes: a new class of organoruthenium anticancer agents. J Inorg Biochem. 2012;106(1):126-133.
81. Dhanaraj CJ, Hassan IU, Johnson J, Joseph J, Joseyphus RS. Synthesis, spectral characterization, DNA interaction, anticancer and molecular docking studies on some transition metal complexes with bidentate ligand. J Photochem Photobiol B. 2016;162:115-124.

82. Kurzwernhart A, Kandioller W, Bächler S, et al. Structure-activity relationships of targeted RuII ( $16-p-C y m e n e)$ anticancer complexes with flavonol-derived ligands. J Med Chem. 2012;55(23):10512-10522.

83. Prajapati R, Dubey SK, Gaur R, et al. Structural characterization and cytotoxicity studies of ruthenium (II)-DMSO-chloro complexes of chalcone and flavone derivatives. Polyhedron. 2010;29:1055-1061.

84. Gaur R, Mishra L. Synthesis and characterization of Ru (II)-DMSOCl-chalcone complexes: DNA binding, nuclease, and topoisomerase II inhibitory activity. Inorg Chem. 2012;51(5):3059-3070.

85. Subasinghe A, Perera IC, Pakhomova S, Perera T. Synthesis, characterization, and biological studies of a piperidinyl appended dipicolylamine ligand and its rhenium tricarbonyl complex as potential therapeutic agents for human breast cancer. Bioinorg Chem Appl. 2016; 2016:2675937.

86. Sava G, Zorzet S, Turrin C, et al. Dual action of NAMI-A in inhibition of solid tumor metastasis selective targeting of metastatic cells and binding to collagen. Clin Cancer Res. 2003;9(5):1898-1905.

87. Sava G, Frausin F, Cocchietto M, et al. Actin-dependent tumour cell adhesion after short-term exposure to the antimetastasis ruthenium complex NAMI-A. Eur J Cancer. 2004;40(9):1383-1396.

88. Heffeter P, Riabtseva A, Senkiv Y, et al. Nanoformulation improves activity of the (pre) clinical anticancer ruthenium complex KP1019. J Biomed Nanotechnol. 2014;10(5):877-884.

89. Trondl R, Heffeter P, Kowol CR, Jakupec MA, Berger W, Keppler BK. NKP-1339, the first ruthenium-based anticancer drug on the edge to clinical application. Chem Sci. 2014;5:2925-2932.
International Journal of Nanomedicine

\section{Publish your work in this journal}

The International Journal of Nanomedicine is an international, peerreviewed journal focusing on the application of nanotechnology in diagnostics, therapeutics, and drug delivery systems throughout the biomedical field. This journal is indexed on PubMed Central, MedLine, CAS, SciSearch ${ }^{\circledR}$, Current Contents ${ }^{\circledR} /$ Clinical Medicine,

\section{Dovepress}

Journal Citation Reports/Science Edition, EMBase, Scopus and the Elsevier Bibliographic databases. The manuscript management system is completely online and includes a very quick and fair peer-review system, which is all easy to use. Visit http://www.dovepress.com/ testimonials.php to read real quotes from published authors. 